\title{
Market channels for prime kids
}

\author{
J. C. LE JAOUEN \\ I.T.O.V.I.C., I 49, we de Bercy, 75579 Paris Cedex I2.
}

In spite of great progress made by the production sector in herd size and organization, as well as in rearing methods, the trade in prime kids remains quite traditional in lirance.

The market requires young animals weighing from 7 to $10 \mathrm{~kg}$, with dressing percentage varying between $6_{5}$ and $67 \%$ for kids fed with goat milk and slaughtered at 3 wecks, and between 60 to $63 \%$ for those fed with milk replacer and slaughtered at 5 or 6 weeks.

Being seasonally produced and quite expensive as compared to other meats, but having the advantage of being a well-characterized traditional product, prime kids are commercialized mostly by poultrymen who play a technical and commercial role, slaughtering, as well as buying from the producer and selling-off the carcasses valorizing the fifth quarticr (skin and rennet stomach).

The present dilemma of the market can be roughly described by the following conflict: whereas the grazers and the skin transformers want heavier kids ( 10 to $12 \mathrm{~kg}$ liveweight), dealers and some consumers are looking for animals of 6 to $7 \mathrm{~kg}$ liveweight, easier to commercialize and having white meat. It seems that the commercial trend is towards light kids.

\section{1. - Free communications}

\author{
I) NUTRITION AND FEEDING
}

\section{Trials on protein supplementation of lambs}

\author{
J. P. CAZES $\left(^{*}\right)$ and E. VAN QUACKEBEKE $\left({ }^{* *}\right)$
}

(*) I.T.C.F., 8, av, du Président-Wilson, 7.5II6 Paris. (**) I.T.O.V.I.C., I 49, nue de Bercy, 75579 Paris Cedex I2

When the same protcin level is used throughout the fattening period, optimum crude protein content of concentrated feed for lambs ranges about $\mathrm{I} 6 \%$ of the dry matter according to our results. However, the protein supply may be reduced during fattening. In male lambs, a diet change from $20 \%$ crude protein, before they reached $25 \mathrm{~kg}$, to I I \% crude protein later, gave the same results as a constant i $6 \%$ crude protein ratio. Females did not react so efficiently to this change.

- Animal performance and concentrate feed efficiency were little affected if soyabcan meal 